\title{
Ovarian Serous Cystadenofibroma
}

National Cancer Institute

\section{Source}

National Cancer Institute. Ovarian Serous Cystadenofibroma. NCI Thesaurus. Code C40032.

A benign neoplasm of the ovary characterized by the presence of cystic structures lined by serous epithelial cells in a fibrotic stroma. 